\title{
Enhanced Classification Guidance, Continue to Promote the Reform Practice of Running Higher Vocational Education between China and Foreign Countries
}

\author{
Xin Zhang, Yuewei Ding, Li Wang and Yihong Fu \\ Shanghai Medical Instrumentation College, Shanghai, China \\ University of Shanghai for Science and Technology, Shanghai, China \\ zhangx@smic.edu.cn,dingyw@smic.edu.cn,wangl@smic.edu.cn, fuyh@smic.edu.cn
}

\begin{abstract}
Enhanced classification guidance, Continue to promote the reform practice of running higher vocational education between China and foreign countries", Is for international research on high-skilled talents training mode of vocational education, also is an important part of the study in High-tech high-skilled talents cultivation mode of colleges. This paper, based on cooperation, mutual recognition of credits, overseas internships, study abroad and overseas undergraduates to elaborate on these four aspects, for example, research on the internationalization of higher vocational talent training practice has important significance and practical value.

Index Terms -Classified guidance, Higher vocational education, running schools between China and foreign countries
\end{abstract}

\section{Introduction}

With the development trend of economic globalization and scientific and technological integration to compete increasingly fierce, international human resources became the core of demand trends and competition, internationalization in higher vocational education also became developing trend [1]. Whether it is cultivating internationalized talents with skillbuilding modern vocational education system, needed to fully experience and absorb useful experience of developed countries.

To meet the needs of local economic and social development, the higher vocational education has been set up after China's reform and opening up. Its orientation is to train highly skilled professional talent. China's high vocational education is in a straight line with the scientific concept of development requirements, striding ahead on the road of sustainable development [2].Development of higher vocational education on the move is full of puzzles and challenges. both is the idea of higher vocational education and the higher vocational education of nature, and there are a range of needs, such as talent training mode in higher vocational education clear, raising awareness, increasing capacity, reform of talents training mode of running an objective demand[3].

Demand for skilled workers at home and abroad increased at the same time, international demand for high-tech high-end high-tech talents is also getting higher and higher, internationalization of high-skilled talents training model in vocational education the necessity and importance of the research speaks for itself[4].
Vocational education must adapt to the new situation, personnel training, combined with the depth of the needs of economic development at home and abroad, relying on the development of domestic industrial transformation and upgrading, and actively explore new mode of talents training in international mechanisms on the cultivation of applied talents with high skill innovation, further optimize talent strategy for the development of the local economy provides a wealth of highly qualified skilled workers and increase their productivity.

\section{Significance}

Higher vocational education is an important part of China's higher education, scale have accounted for half of the higher vocational education bears training production line with high technical high-technical talent of important tasks. Since 2008 the Ministry of Education started "national model sexual high career colleges construction plans", high career colleges in school enterprises cooperation institutional mechanism, and workers learn combines talent training mode, and double divisions team, and experiment real training construction, and social service, aspects are has formed has stark of features, in connotation construction aspects are made has strides, model colleges were full played has development, reform, management of model and led role. These are rich has high vocational colleges international exchange and cooperation of platform and space. For the internationalization of higher vocational education has brought new opportunities and challenges.

\section{A. Internationalization of Higher Vocational Education is the Product of Economic Globalization}

With China's accession to WTO and the deepening of the reform and opening up, the development trend of economic globalization and scientific and technological integration to compete increasingly fierce. With the arrival of knowledge economy era, high-end application-oriented talents cultivation issues are increasingly becoming the focus of attention. With the increasingly frequent exchanges between international, an international human resources becoming the core of demand trends and competition[5] [6]. Higher vocational education is

\footnotetext{
* This work is financed by the Shanghai Institute of Higher Education's 2013 project.
} 
an important foundation for China's economic and social development. It is an important pillar of realizing industrialization and modernization. It is an important measure to enhance China's comprehensive national strength and core competitive power and means. Therefore, development of China's higher vocational education must adapt ted the new situation, combined with the depth of the needs of economic development at home and abroad, relying on the development of domestic industrial transformation and upgrading, and actively explore the internationalization of higher vocational education.

\section{B. Internationalization of Higher Vocational Education is the Reform and Development Trend}

Higher vocational education has dual attributes of higher education and vocational education. Higher education is the essence of advanced knowledge creation and transmission. While knowledge is borderless, have a certain international. Therefore, in the reform and development of higher education, needs to be done to extend and strengthen its international academic exchange and cooperation, cultivating international personnel functions [7]. Vocational education not only to teach students the knowledge and, more importantly, for the cultivation of the students ' professional skills, particularly in a globalized economic environment, the vocational education reform and development need to take the challenge of internationalization of vocational qualification standards in the international market[8].

Higher vocational education talent training goal is to adapt production, construction, management and service line application-oriented expertise in advanced technology[9]. Relying on the internationalization of higher vocational education, in international high mechanisms on the quality cultivation of high-skilled talents in innovation to further broaden the international perspective and optimize talent strategy for internationalization of developing local economy offers a wide range of high-quality technical talents, is the modern trend of higher vocational education reform and development.

\section{Internationalization of Higher Vocational Education is the Guarantee in Speeding up the Construction of Modern Vocational Education System}

Under the new situation, Society has new demanded on technology skills levels, specifications, new knowledge and capacity. Built to adapt to economic and social development and upgrading needs of modern vocational education system, into the world of vocational education system is imperative.

Higher vocational education "with Chinese characteristics, standard of the world" in the construction of the modern vocational education system bears an unshirkable historical responsibility.

It will play a catalytic role in connecting with secondary vocational and higher vocational education. At the same time, it will play a backbone role in connecting with Vocational, undergraduate, masters.
Achieved high vocational education internationalization, through and international education institutions, and enterprise of exchange and cooperation, full uses international education market, gradually release domestic education market. adapted international dating and development of needs in education target, education content and method, efforts training has international development consciousness, international dating capacity and international competitiveness of high quality workers and high skills applied talent, to accelerated our modern vocational education system of construction, led our high vocational education rapid integration in the world vocational education system.

\section{Procedures for Implementing Enhanced Classification Guidance}

Educational needs of forward-looking, talent not only to adapt to the current domestic market needs, but also to fully meet the requirements of a market economy in China and abroad in the late.

Drill down to the curriculum and teaching reform of talent-training pattern for primary content and promote internationalization of vocational education in Shanghai Medical Instrumentation College.

\section{A. Cooperation in Running Schools}

"Clinical Engineering Technology (Sino-Japanese cooperative medical electronics engineering)" and OSAKA JIKEI COLLEGE has Chinese-foreign cooperation in running schools.

TABLE I Contents of "Clinical Engineering" Professional Training

\begin{tabular}{|c|c|c|c|}
\hline \multirow{2}{*}{ No. } & \multicolumn{3}{|c|}{ Appearance } \\
\cline { 2 - 5 } & Contents of Training & $\begin{array}{c}\text { Credit } \\
\text { Hours }\end{array}$ & Results Form \\
\hline 1 & $\begin{array}{c}\text { Medical Treatment Equipment } \\
\text { for Hemodialysis Machine } \\
\text { Training }\end{array}$ & 40 & $\begin{array}{c}\text { Cuedits } \\
\text { Training Report }\end{array}$ \\
\hline 2 & $\begin{array}{c}\text { Japan language and Culture } \\
\text { Studies }\end{array}$ & 40 & $\begin{array}{c}\text { Cuedits } \\
\text { Training Report }\end{array}$ \\
\hline 3 & Internships in Hospitals & 24 & Training Report \\
\hline 4 & internships in the MINATO & 24 & Training report \\
\hline 5 & internships in the NIPRO & 24 & $\begin{array}{c}\text { NCU-12 Hemodialysis } \\
\text { Certificate }\end{array}$ \\
\hline 6 & Asia Clinical Science Forum & 8 & Best Paper Award \\
\hline
\end{tabular}

Hiring Japanese teachers taught, deepen the curriculum reform, introducing Japan teaching materials. Japanese teaching and the introduction of textbooks is deepen the curriculum reform and the breakthrough. Japan in the clinical training of engineering technician qualifications process, has developed a variety of advanced concepts, optimized structure, contents application of innovative, international textbooks, 
have had a significant impact. Cooperative education training experience and learn from each other's results. Contents of "Clinical Engineering" Professional Training as is shown in Table I.

Planning for 60 students per session annually sent about 40 students and 2-3 teachers in Japan for a period of 1 months of professional training.

\section{B. Mutual Recognition of Credits}

Global interoperability based on information technologies, "Health Information Management" professional lead in updating lesson plans, and the University of The Fraser Valley cooperation through professional standards, curriculum, personnel evaluation standards of teaching evaluation standard and certificate standards with international standards through mutual recognition of credits.

Has signed an agreement to mutual recognition of 74 units. Contents of "Health Information Management Professional" Professional Training as is shown in Table II.

Planning for 60 students per session annually send about 5 students and 1 teacher in Canada University of the Fraser Valley for a period of 3 months of professional training.

TABLE II Contents of "Health Information Management Professional" Training

\begin{tabular}{|c|c|c|c|}
\hline \multirow{2}{*}{ No. } & \multicolumn{3}{|c|}{ Appearance } \\
\cline { 2 - 5 } & Contents of Training & $\begin{array}{r}\text { Credit } \\
\text { Hours }\end{array}$ & Results Form \\
\hline 1 & $\begin{array}{c}\text { Computer Maintenance and } \\
\text { Communication Technology }\end{array}$ & 40 & Credits \\
\hline 2 & English Study Learning & 80 & Credits \\
\hline 3 & Medical Information System & 40 & Credits \\
\hline 4 & Virtual Reality Technology (3D printer) & 40 & Test Report \\
\hline 5 & Internship in Canada Hospital & 24 & Training Report \\
\hline
\end{tabular}

\section{Study Abroad and International Internship}

Over the next five years, as China's improving economic competitiveness in the world economy, will further increase the demand for bilingual professional talent. These talents necessary to master the advanced theoretical knowledge and practical skills, proficiency in a foreign language, be good at working in a foreign language and communication.

"Medical Electronic Instrumentation and Protection" with Niagara University College, students study abroad agreements concluded. Contents of "Medical Electronic Instrumentation and Protection" Professional Training as is shown in Table III.

Planning for 60 students per session annually send about 10 students and 1 teacher in Canada Niagara College for a period of 1 months of professional training.
TABLE III Contents of "Medical Electronic Instrumentation and Protection" Training

\begin{tabular}{|c|c|c|c|}
\hline \multirow{2}{*}{ No. } & \multicolumn{3}{|c|}{ Appearance } \\
\hline & Contents of Training & $\begin{array}{l}\text { Credit } \\
\text { Hours }\end{array}$ & Results Form \\
\hline 1 & $\begin{array}{l}\text { Advanced measurement } \\
\text { principle and application }\end{array}$ & 40 & Credits \\
\hline 2 & English Study Learning & 80 & $\begin{array}{c}\text { Credits } \\
\text { Training Certificate }\end{array}$ \\
\hline 3 & $\begin{array}{c}\text { Application of Microelectronic } \\
\text { Technology }\end{array}$ & 40 & Test Report \\
\hline 4 & $\begin{array}{l}\text { Medical Electronic } \\
\text { Technology }\end{array}$ & 40 & Test Report \\
\hline 5 & Internship in Canada Hospital & 24 & Training Report \\
\hline
\end{tabular}

Study abroad I -language learning helps students learn and understand the culture abroad, learning and different thinking and dialogue systems and cultural backgrounds of people. Help students with foreign staff to work together in the future to broaden employment channels, expand employment opportunities, improve their employability.

Study abroad II- major study help with foreign experts, engineers, technicians, professional exchange and discussion on frontier issues, which in future work in a timely manner to solve the problem of production, labour, promoting the innovation of enterprise.

\section{Overseas undergraduate}

Global evaluation of occupational skills, unified standards, harmonization of accreditation, is a big trend. The experiences of foreign educational resources and has established vocational system, "Health Information Management" professional and Griffith College (Ireland Griffith College) cooperation; "Medical Electronic Equipment and Maintain" professional and San Jose State University (United States San Jose State University).

Retain the parties 'respective teaching model by assessing each other's schools offer courses, mutual recognition of credits, allows students to receive diplomas issued by schools. Actively expand the students upgraded channel.

Developing higher vocational education so that gradually to undergraduate and graduate-level development of vocational education, creating a cut-through of the vocational education system.

\section{Prospect}

Because of overseas companies to participate more broadly in international competition, they accelerate the technology development and transfer process, will lead to changing the scientific and technological content of the job.

Cultivating talents based on global vision medical talents with high skill, cultivating internationalized talents of vocational education, not missing overseas enterprises involved. 
Actively expanding overseas enterprise work experience and internships. On the curriculum setting of each mode, and to learn from the international experience of overseas firms, making it flexible in adjusting jobs brought about by economic globalization and scientific and technological content, meet the needs of students ' career.

Advantages of using overseas companies, actively developing shorter non-degree vocational certificate of education. Genuine implementation of work-integrated learning, talents training mode of close cooperation of school and enterprise.

\section{References}

[1] Wu Zhongwen, "Times'Call for Vocational Education Ver.3.0," China Youth. http://zqb.cyol.com/January 2013.

[2] Li Wang, Xin Zhang, Yuewei Ding and Jieting Wang, "Inspiration on the Australian Vocational Education and the Referential Significance to
SMIC," Education Technology and Managment Science, pp.961-964, July 2013.

[3] Xu Kuihong, Zhang Rongjuan, "Study Oil the Administration System of Community College in the USA, "Vocational and Technical Education." pp. 79-82, 2012, Vol33(16).

[4] Yuewei Ding,Li Wang, Yihong Fu, Hong Chen, "The Revelation and Practice of the Multi-level, Multi-direction Educantion Model of The American Community Colleges," Education Technology and Managment Science,pp.965-968,2013.

[5] Yixoan Li, "American community colleges," Distance Education in China. 2008, http://www.chinagaozhi.org/models/gz/.

[6] Gavin Moodie, Leesa Wheelahan, "The Significance of Australian Vocational Education Institutions in Opening Access to Higher Education," Higher Education Quarterly, pp.88-91, Vol63, No4, 2009.

[7] Xianliang Liu, "The reform and development of higher vocational colleges," http://sfb.yrcti.edu.cn/showart.asp, 2007-8-23.

[8] Patterson, D.J, "The development of a bachelor of engineering program at the Northern Territory University, "Australia , Education, IEEE Transactions, pp.178-183,1994, Vol37(2). 